\title{
Three new pyrrole alkaloids from the endophytic fungus Albifimbria viridis
}

\author{
Pan-Pan Wei, Jia-Cheng Ji, Xu-Jun Ma, Zheng-Hui Li, Hong-Lian Ai* ${ }^{*}$, Xin-Xiang Lei ${ }^{*}$ and Ji-Kai Liu*
}

\begin{abstract}
Three new pyrrole alkaloids albifipyrrols A-C (1-3), were isolated from the endophytic fungus Albifimbria viridis collected from the Chinese medicinal plant. Their structures were elucidated by extensive NMR and HRESIMS spectrometric analyses. All compounds were evaluated for immunosuppressive activity. Fortunately, compound $\mathbf{2}$ exhibits certain inhibition specifically against the LPS-induced proliferation of B lymphocyte cells with $I C_{50}$ value $16.16 \mu \mathrm{M}$.
\end{abstract}

Keywords: Pyrrole alkaloids, Coptis chinensis, Endophytic fungus, Albifimbria viridis, Immunosuppressive activity Graphical Abstract

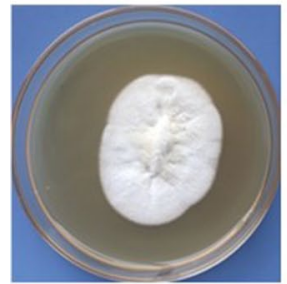

Albifimbria viridis

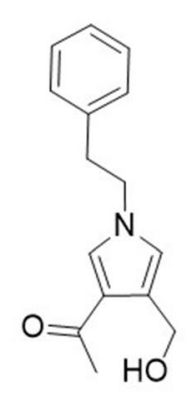

1

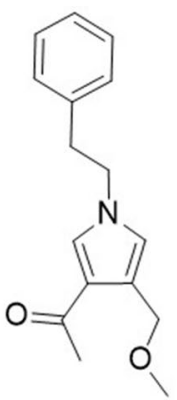

2

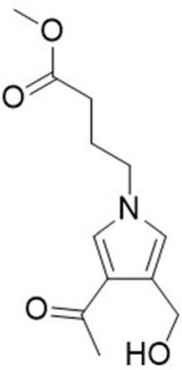

3

\section{Introduction}

The human immune system is a complex network of defensing against foreign invaders. Autoimmune diseases arise when the immune system fails to distinguish between self and non-self [1, 2]. Immunosuppressants are often used to prevent and treat the immune rejection of organs and tissues of transplant patients and play an important role in the treatment of various autoimmune diseases [3-8]. Nevertheless, some common immunomodulatory drugs such as mycophenolate mofetil (MMF) and cyclosporin A (CsA) have low efficacy,

*Correspondence: aihonglian@mail.scuec.edu.cn; xxlei@mail.scuec.edu.cn; liujikai@mail.scuec.edu.cn

School of Pharmaceutical Sciences, South-Central University

for Nationalities, Wuhan 430074, People's Republic of China toxicity, and serious side effects in transplant patients [912]. Therefore, it is necessary to find more efficient, safe and novel immunosuppressants to improve rejection.

In recent years, endophytic fungi from plants have been widely regarded as a significant source of drugs [13]. A great quantity of compounds with novel structures and multiple bioactivities are constantly isolated [14-16]. For instance, the well-known anticancer drug paclitaxel can be produced from Pacific yew by the endophytic fungus Taxomyces andreance [17]. Coptis chinensis Franch is a famous Chinese medicine in China. Modern pharmacological and clinical studies have indicated that it has anti-tumor, anti-inflammatory, antibacterial, hypoglycemic and other pharmacological activities [18-20]. However, there 
are few reports on endophytic fungus of $C$. chinensis Franch.

During the past few years, we had the aim of finding new potential immunosuppressive agents from endophytic fungus of C.chinensis Franch. Fortunately, we obtained a pyrrole alkaloid with immunosuppressive activity from Albifimbria viridis. Herein, we report the details of the isolation, structure elucidation, and bioactivities of three pyrrole alkaloids albifipyrrols A-C (1-3) (Fig. 1).

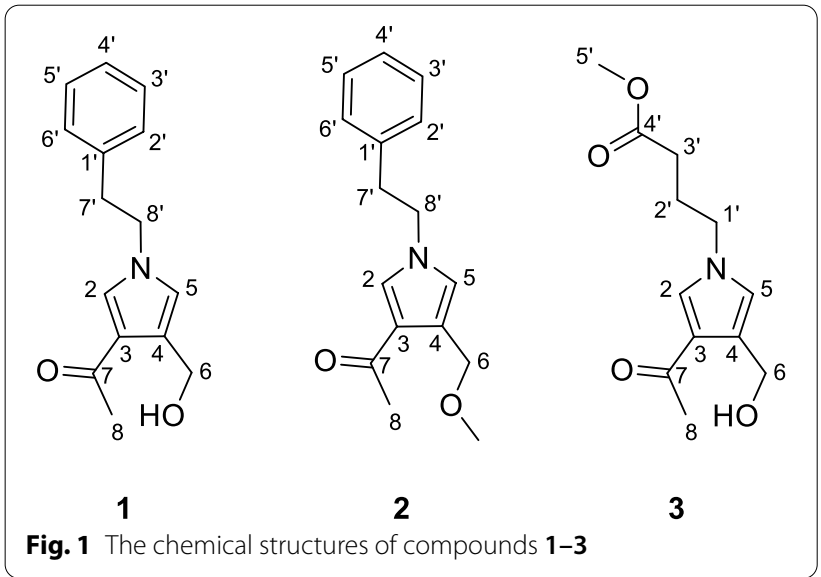

\section{Results and discussion}

Compound 1 was obtained as yellow oil. The molecular ion peak of HR-ESI-MS was at $m / z 266.1150[\mathrm{M}+\mathrm{Na}]^{+}$ (calcd for 266.1157), which indicated that the molecular formula of compound $\mathbf{1}$ is $\mathrm{C}_{15} \mathrm{H}_{17} \mathrm{NO}_{2}$, with eight degrees of unsaturation. In the ${ }^{1} \mathrm{H}$-NMR spectrum (Table 1), a monosubstituted benzene moiety at $\delta_{\mathrm{H}} 7.13$ $\left(2 \mathrm{H}, \mathrm{d}, J=7.8 \mathrm{~Hz}, \mathrm{H}-2^{\prime}, \mathrm{H}-6^{\prime}\right), 7.24-7.28\left(2 \mathrm{H}, \mathrm{m}, \mathrm{H}-3^{\prime}\right.$, $\left.\mathrm{H}-5^{\prime}\right)$ and $7.18-7.22\left(1 \mathrm{H}, \mathrm{m}, \mathrm{H}-4^{\prime}\right)$, two mutually coupling aromatic protons at $\delta_{\mathrm{H}} 6.72(1 \mathrm{H}, \mathrm{d}, J=2.2 \mathrm{~Hz}$, $\mathrm{H}-5)$ and $7.40(1 \mathrm{H}, \mathrm{d}, J=2.2 \mathrm{~Hz}, \mathrm{H}-2)$, two heteroatombearing methylenes at $\delta_{\mathrm{H}} 4.56(2 \mathrm{H}, \mathrm{s}, \mathrm{H}-6)$ and $4.16(2 \mathrm{H}$, $\left.\mathrm{t}, J=7.1 \mathrm{~Hz}, \mathrm{H}-8^{\prime}\right)$, one conventional methylene at $\delta_{\mathrm{H}}$ $3.06\left(2 \mathrm{H}, \mathrm{t}, J=7.1 \mathrm{~Hz}, \mathrm{H}-7^{\prime}\right)$ and one methyl group at $\delta_{\mathrm{H}}$ $2.32(3 \mathrm{H}, \mathrm{s}, \mathrm{H}-8)$ were clearly shown. The ${ }^{13} \mathrm{C}-\mathrm{NMR}$ and DEPT spectrum (Table 1) of $\mathbf{1}$ showed the presence of fifteen carbons, including one methyl, three methylenes [including two heteroatom-bearing methylenes at $\delta_{\mathrm{C}} 58.5$ (C-6), $\left.52.5\left(\mathrm{C}-8^{\prime}\right)\right]$, seven aromatic or olefinic methines and four nonprotonated carbons [including one ketone carbonyl at $\left.\delta_{\mathrm{C}} 197.4(\mathrm{C}-7)\right]$. Among them, one benzene ring, an acetyl group and four olefinic carbons occupied seven degrees of unsaturation. Hence, the remaining one degree of unsaturation can only be due to the presence of one ring. The key $\mathrm{HMBC}$ correlations (Fig. 2) from $\mathrm{H}-2$ to $\mathrm{C}-3 / \mathrm{C}-4 / \mathrm{C}-5$ and from $\mathrm{H}-5$ to $\mathrm{C}-2 / \mathrm{C}-3 / \mathrm{C}-4$ and from $\mathrm{H}-8^{\prime}$ to $\mathrm{C}-2 / \mathrm{C}-5$ demonstrated the existence of a pyrrole

Table $1{ }^{1} \mathrm{H}$ and ${ }^{13} \mathrm{C}$ NMR data ( $\delta$ in ppm and $J$ in $\mathrm{Hz}$ ) of compounds $\mathbf{1}-\mathbf{3}$

\begin{tabular}{|c|c|c|c|c|c|c|}
\hline No. & 1 & & 2 & & 3 & \\
\hline & $\delta_{C}^{a}$ & $\delta_{H}{ }^{b}$, mult $(J)$ & $\delta_{C}^{a}$ & $\delta_{H}{ }^{b}$, mult $(J)$ & $\delta_{C}{ }^{c}$ & $\delta_{H}{ }^{d}$, mult $(J)$ \\
\hline 2 & $131.8, \mathrm{CH}$ & $7.40, \mathrm{~d}(2.2)$ & $130.9, \mathrm{CH}$ & $7.36, d(2.2)$ & $131.6, \mathrm{CH}$ & $7.61, d(2.2)$ \\
\hline 3 & $123.9, \mathrm{C}$ & & $123.5, \mathrm{C}$ & & $124.3, \mathrm{C}$ & \\
\hline 4 & $126.7, \mathrm{C}$ & & $123.1, \mathrm{C}$ & & $127.0, \mathrm{C}$ & \\
\hline 5 & $122.4, \mathrm{CH}$ & $6.72, d(2.2)$ & $123.7, \mathrm{CH}$ & $6.70, d(2.2)$ & $122.4, \mathrm{CH}$ & $6.77, d(2.2)$ \\
\hline 6 & $58.5, \mathrm{CH}_{2}$ & $4.56, \mathrm{~s}$ & $68.6, \mathrm{CH}_{2}$ & $4.54, d(0.8)$ & $58.5, \mathrm{CH}_{2}$ & $4.59, \mathrm{~d}(0.8)$ \\
\hline 6-OMe & & & $58.2, \mathrm{CH}_{3}$ & $3.34,5$ & & \\
\hline 7 & $197.4, C$ & & $196.4, C$ & & $197.5, \mathrm{C}$ & \\
\hline 8 & $26.9, \mathrm{CH}_{3}$ & $2.32, \mathrm{~s}$ & $27.3, \mathrm{CH}_{3}$ & $2.29, \mathrm{~s}$ & $27.0, \mathrm{CH}_{3}$ & $2.40, \mathrm{~s}$ \\
\hline $1^{\prime}$ & $139.5, \mathrm{C}$ & & $139.5, \mathrm{C}$ & & $49.9, \mathrm{CH}_{2}$ & $3.99, \mathrm{t}(7.0)$ \\
\hline $2^{\prime}$ & 129.9,CH & $7.13, d(7.8)$ & 129.9, CH & $7.12, \mathrm{~d}(7.8)$ & $27.4, \mathrm{CH}_{2}$ & $2.08, \mathrm{~m}$ \\
\hline $3^{\prime}$ & $129.6, \mathrm{CH}$ & $7.24-7.28, \mathrm{~m}$ & $129.6, \mathrm{CH}$ & $7.23-7.27, \mathrm{~m}$ & $31.4, \mathrm{CH}_{2}$ & $2.32, \mathrm{t}(7.3)$ \\
\hline $4^{\prime}$ & 127.7, CH & $7.18-7.22, \mathrm{~m}$ & $127.7, \mathrm{CH}$ & $7.18-7.22, \mathrm{~m}$ & $174.8, \mathrm{C}$ & \\
\hline $5^{\prime}$ & $129.6, \mathrm{CH}$ & $7.24-7.28, \mathrm{~m}$ & $129.6, \mathrm{CH}$ & $7.23-7.27, \mathrm{~m}$ & $52.2, \mathrm{CH}_{3}$ & $3.65, \mathrm{~s}$ \\
\hline $6^{\prime}$ & 129.9,CH & $7.13, d(7.8)$ & $129.9, \mathrm{CH}$ & $7.12, \mathrm{~d}(7.8)$ & & \\
\hline $7^{\prime}$ & $38.6, \mathrm{CH}_{2}$ & $3.06, \mathrm{t}(7.1)$ & $38.7, \mathrm{CH}_{2}$ & $3.06, t(7.1)$ & & \\
\hline $8^{\prime}$ & $52.5, \mathrm{CH}_{2}$ & $4.16, t(7.1)$ & $52.5, \mathrm{CH}_{2}$ & $4.16, \mathrm{t}(7.1)$ & & \\
\hline
\end{tabular}

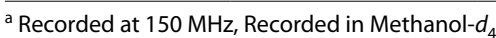

${ }^{\mathrm{b}}$ Recorded at $600 \mathrm{MHz}$, Recorded in Methanol- $d_{4}$

${ }^{c}$ Recorded at $126 \mathrm{MHz}$, Recorded in Methanol- $d_{4}$

${ }^{d}$ Recorded at $500 \mathrm{MHz}$, Recorded in Methanol- $d_{4}$ 

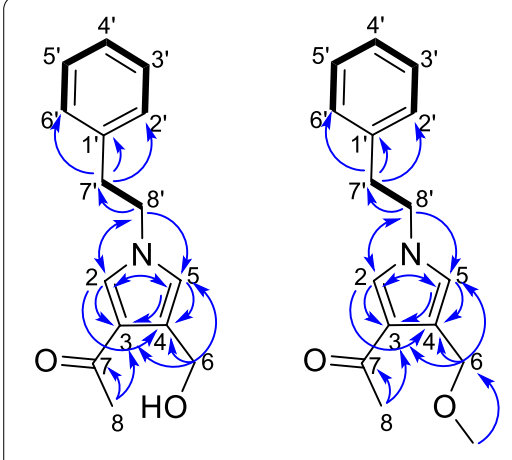

2

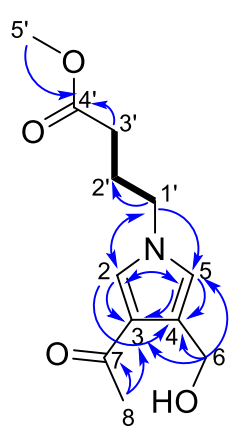

3
${ }^{1} \mathrm{H}-{ }^{1} \mathrm{H}$ COSY

$\sim \mathrm{HMBC}$

Fig. 2 Key HMBC and ${ }^{1} \mathrm{H}-{ }^{1} \mathrm{H}$ COSY correlations of compounds $\mathbf{1}-\mathbf{3}$

nucleus. The ${ }^{1} \mathrm{H}^{1}{ }^{1} \mathrm{H}$ COSY correlations (Fig. 2) between $\mathrm{H}_{2}-7^{\prime}$ and $\mathrm{H}_{2}-8^{\prime}$ and the key HMBC correlations from $\mathrm{H}-7^{\prime}$ to $\mathrm{C}-1^{\prime} / \mathrm{C}-2^{\prime} / \mathrm{C}-6^{\prime}, \mathrm{H}-8^{\prime}$ to $\mathrm{C}-2 / \mathrm{C}-5 / \mathrm{C}-7^{\prime}$ showed the phenylethyl was attached to the nitrogen atom. In addition, the acetyl can be confirmed by the key HMBC correlation from $\mathrm{H}-8$ to C-7. Finally, the locations of the two substituents (an acetyl group and an ethoxy group) on the pyrrole nucleus were also confirmed at C-3, C-4 based on the $\mathrm{HMBC}$ correlations from $\mathrm{H}-8$ to $\mathrm{C}-3$ and from $\mathrm{H}-6$ to C-3/C-4/C-5. Compound 1 was, therefore, established as albifipyrrol A, as depicted.

Compound 2 was obtained as yellow oil. The molecular ion peak of HR-ESI-MS was at $\mathrm{m} / z 280.1306[\mathrm{M}+\mathrm{Na}]^{+}$ (calcd for 280.1313), which deduced that the molecular formula of compound 2 was $\mathrm{C}_{16} \mathrm{H}_{19} \mathrm{NO}_{2}$, with eight degrees of unsaturation. The ${ }^{1} \mathrm{H}-\mathrm{NMR}$ and ${ }^{13} \mathrm{C}-\mathrm{NMR}$ data (Table 1) suggested $\mathbf{2}$ was similar to 1 and the only observed difference was that the hydroxy group in $\mathbf{1}$ was replaced by a methoxy group in 2 . This change can be confirmed by the key HMBC correlations (Fig. 2) from $\mathrm{H}_{3}$-OMe to C-6. Compound 2 was, therefore, established as albifipyrrol B, as depicted.

Compound 3 was obtained as yellow oil. The molecular ion peak of HR-ESI-MS is at $m / z 262.1046[\mathrm{M}+\mathrm{Na}]^{+}$ (calcd for 262.1055), which indicated that the molecular formula of compound 3 is $\mathrm{C}_{12} \mathrm{H}_{17} \mathrm{NO}_{4}$, with five degrees of unsaturation. The ${ }^{1} \mathrm{H}-\mathrm{NMR}$ (Table 1 ) and HSQC spectrum of $\mathbf{3}$ revealed $\mathbf{3}$ has the same pyrrole ring as $\mathbf{1}$ and the major difference was the substituents on nitrogen. The ${ }^{1} \mathrm{H}$-NMR showed the signals of one methoxy $\left[\delta_{\mathrm{H}}\right.$ $\left.3.65\left(3 \mathrm{H}, \mathrm{s}, \mathrm{H}-5^{\prime}\right) ; \delta_{\mathrm{C}} 52.2\left(\mathrm{C}-5^{\prime}\right)\right]$, one carboxyl group $\left[\delta_{\mathrm{C}}\right.$ $\left.174.8\left(\mathrm{C}-4^{\prime}\right)\right]$, three methylenes $\left[\delta_{\mathrm{H}} 2.32(2 \mathrm{H}, \mathrm{t}, J=7.3 \mathrm{~Hz}\right.$, $\left.\mathrm{H}-3^{\prime}\right), 2.08\left(2 \mathrm{H}, \mathrm{m}, \mathrm{H}-2^{\prime}\right), 3.99\left(2 \mathrm{H}, \mathrm{t}, J=7.0 \mathrm{~Hz}, \mathrm{H}-1^{\prime}\right) ; \delta_{\mathrm{C}}$

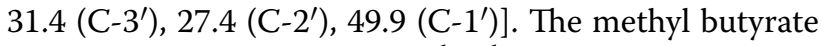
unit was established by the ${ }^{1} \mathrm{H}_{-}{ }^{1} \mathrm{H}$ COSY correlations
Table 2 Immunosuppressive tests of compounds 1-3

\begin{tabular}{lll}
\hline Compound & $\begin{array}{l}\text { ConA-induced T-cell } \\
\text { proliferation }\end{array}$ & $\begin{array}{l}\text { LPS-induced } \\
\text { B-cell } \\
\text { proliferation }\end{array}$ \\
$\mathbf{I C}_{50}(\boldsymbol{\mu M})$
\end{tabular}

between $\mathrm{H}_{2}-1^{\prime}, \mathrm{H}_{2}-2^{\prime}$ and $\mathrm{H}_{2}-3^{\prime}$ and the key HMBC correlations (Fig. 2) from $\mathrm{H}-5^{\prime}$ to $\mathrm{C}-4^{\prime}$ and from $\mathrm{H}-3^{\prime}$ to $\mathrm{C}-4^{\prime}$. Finally, the attachment position of the methyl butyrate residue to the pyrrole ring was defined on the basis of HMBC correlations between $\mathrm{H}-1$ 'and $\mathrm{C}-2 / \mathrm{C}-5$. Compound 3 was, therefore, established as albifipyrrol $\mathrm{C}$, as depicted.

All new compounds were evaluated for their in vitro inhibition activities on concanavalin A (Con A) induced $T$ cell proliferation and lipopolysaccharide (LPS) induced B cell proliferation. Compound 2 exhibited certain inhibition specifically against the LPS-induced proliferation of B lymphocyte cells with $\mathrm{IC}_{50}$ value $16.6 \mu \mathrm{M}$ (Table 2).

\section{Experimental section}

\subsection{General experimental procedures}

1D and 2D NMR spectra were recorded on Bruker DXR-600 instrument (600 and $150 \mathrm{MHz}$ ) and Bruker DXR-500 instrument (500 and $126 \mathrm{MHz}$ ). The UV data were detected by Hitachi UH5300 spectrophotometer (Hitachi, Kyoto, Japan). IR spectra were conducted on IRT racer-100 (SHIMADZU, Kyoto, Japan) with $\mathrm{KBr}$ pellets. HR-ESI-MS data were obtained on a UPLC-Q Exactive MS system (Thermo Fisher, Santa Clara, CA, USA). The packing for column chromatography (CC) is silica gel (200-300 mesh, Qingdao Haiyang Chemical Co., Ltd., Qingdao, China) or Sephadex LH-20 (Amersham Biosciences, Upssala, Sweden). The semi-prepared HPLC was carried out on an Agilent Technologies 1260 Infinity II system with a diode array detector. And the chromatographic column was $\mathrm{C}_{18}$ reversed phase column $(5 \mu \mathrm{m}, 10 \times 250 \mathrm{~mm})$ (Agela, Tianjin, China).

\subsection{Fungal material}

The strain were isolated from the roots of $C$. chinensis collected from Enshi, Hubei province, and was identified as Albifimbria viridis via $18 \mathrm{~S}$ rDNA sequences and deposited at South-Central University for Nationalities, China. The sequence data for this strain had been 
submitted to the DDBJ/EMBL/Genbank with accession No. MT110686.1.

\subsection{Extraction and isolation}

The fungus Albifimbria viridis was fermented on solid rice medium $(100 \mathrm{~g}$ of rice, $100 \mathrm{~mL}$ of water, in each $500 \mathrm{~mL}$ culture flask) and was cultured at $30^{\circ} \mathrm{C}$ for one month. The fermented material was soaked in absolute methanol $(20 \mathrm{~L} \times 4)$. The combined extracts were evaporated under reduced pressure to afford an crude extract, which was further dissolved in water and extracted three times with EtOAc $(10 \mathrm{~L} \times 4)$ to yield $110 \mathrm{~g}$ of the extract. The crude extract was subjected to silica gel column chromatography (petroleum ether: ethyl acetate, 15:1 to 0:1; ethyl acetate: methyl alcohol, $15: 1$ to $0: 1$ ) to yield six fractions $(\mathrm{A}-\mathrm{F})$. Fraction $\mathrm{B}(6 \mathrm{~g})$ was separated into eight sub-fractions $\left(\mathrm{B}_{1}-\mathrm{B}_{8}\right)$ by ODS MPLC. The eluent is composed of methyl alcohol: $\mathrm{H}_{2} \mathrm{O}$ (from 10:90 to 100:0, $\mathrm{v} / \mathrm{v})$. Fraction $\mathrm{B}_{3}$ was purified by semi-preparative HPLC $\left(\mathrm{CH}_{3} \mathrm{CN} / \mathrm{H}_{2} \mathrm{O}=55: 45, \mathrm{v} / \mathrm{v}\right)$ to give compound $\mathbf{1}(4.7 \mathrm{mg}$, $\left.t_{\mathrm{R}}=18.7 \mathrm{~min}\right)$. Fraction C (5 g) was isolated from Sephadex LH-20 eluting with $\mathrm{MeOH}$ and purified by semipreparative HPLC $\left(\mathrm{CH}_{3} \mathrm{CN} / \mathrm{H}_{2} \mathrm{O}=40: 60\right.$, v/v $)$ to obtain compound 2 ( $\left.1.3 \mathrm{mg}, t_{\mathrm{R}}=25 \mathrm{~min}\right)$. Fraction $\mathrm{D}(7.5 \mathrm{~g})$ was isolated by Sephadex LH-20 column chromatography $(\mathrm{MeOH})$ to obtain six sub-fractions $\left(\mathrm{D}_{1}-\mathrm{D}_{6}\right)$. Fraction $\mathrm{D}_{5}$ was purified by semi-preparative HPLC $\left(\mathrm{CH}_{3} \mathrm{CN} / \mathrm{H}_{2} \mathrm{O}\right.$ from $25: 75$ to $45: 55$ in $20 \mathrm{~min}, \mathrm{v} / \mathrm{v}$ ) to yield compound 3 $\left(2.4 \mathrm{mg}, t_{\mathrm{R}}=13.2 \mathrm{~min}\right)$.

\subsection{Spectroscopic data of compounds \\ 3.4.1 Albifipyrrol A (1)}

Yellow oil. UV $(\mathrm{MeOH}) \lambda_{\max }(\log \varepsilon): 210$ (1.97). HRESI-MS $\mathrm{m} / \mathrm{z}$ found $266.1150 \quad[\mathrm{M}+\mathrm{Na}]^{+}$(Calcd for $\left.\mathrm{C}_{15} \mathrm{H}_{17} \mathrm{NO}_{2} \mathrm{Na}, 266.1157\right)$. IR ( $\left.\mathrm{KBr}\right) v_{\max }\left(\mathrm{cm}^{-1}\right)$ : 3401, 2949, 2837, 1655, 1450, 1117, 1024. ${ }^{1} \mathrm{H}$ and ${ }^{13} \mathrm{C}$-NMR see (Table 1).

\subsubsection{Albifipyrrol B (2)}

Yellow oil. UV (MeOH) $\lambda \max (\log \varepsilon): 210$ (1.82). HRESI-MS $\mathrm{m} / \mathrm{z}$ found 280.1306 $[\mathrm{M}+\mathrm{Na}]^{+}$(Calcd for $\left.\mathrm{C}_{16} \mathrm{H}_{19} \mathrm{NO}_{2} \mathrm{Na}, 280.1313\right)$. IR (KBr) $v_{\max }\left(\mathrm{cm}^{-1}\right)$ : 3364, 2945, 2833, 1670, 1452, 1119, 1032. ${ }^{1} \mathrm{H}$ and ${ }^{13} \mathrm{C}-\mathrm{NMR}$ see (Table 1).

\subsubsection{Albifipyrrol C (3)}

Yellow oil. UV $(\mathrm{MeOH}) \lambda_{\max }(\log \varepsilon): 255$ (2.01). HRESI-MS $\mathrm{m} / \mathrm{z}$ found $262.1046[\mathrm{M}+\mathrm{Na}]^{+}$(Calcd for $\left.\mathrm{C}_{12} \mathrm{H}_{17} \mathrm{NO}_{4} \mathrm{Na}, 262.1055\right)$. IR ( $\left.\mathrm{KBr}\right) v_{\max }\left(\mathrm{cm}^{-1}\right)$ : 3400, 2950,1734, 1632, 1526, 1157. ${ }^{1} \mathrm{H}$ and ${ }^{13} \mathrm{C}-\mathrm{NMR}$ see (Table 1).

\subsection{Immunosuppressive activities assay}

Fresh spleen cells were obtained from female BALB/c mice (6-8 weeks old). Spleen cells $\left(1 \times 10^{6}\right.$ cells) were cultured in triplicate on a 96-well plate for $48 \mathrm{~h}$ at $37^{\circ} \mathrm{C}$ in a humidified incubator containing $5 \% \mathrm{CO}_{2}$ (with or without different concentrations of compounds). During the last $8 \mathrm{~h}$ of culture, a certain amount of CCK- 8 was added to each well. At the end of culture, the OD values at $450 \mathrm{~nm}$ was measured by a bio-RAD 650 microplate reader. Cells with viability above $85 \%$ were further screened for their inhibitory activity against $\mathrm{T}$ and $\mathrm{B}$ lymphocytes. The $5 \times 10^{5}$ spleen cells were cultured at the same conditions as those mentioned above. $T$ cell or $B$ cell proliferation was induced with $10 \mu \mathrm{g} \mathrm{ml} l^{-1}$ of LPS or $5 \mu \mathrm{g} \mathrm{m}{ }^{-1}$ of ConA, respectively. Proliferation was assessed in terms of uptake of $\left[{ }^{3} \mathrm{H}\right]$-thymidine during $8 \mathrm{~h}$ of pulsing with $25 \mu \mathrm{L} /$ well of $\left[{ }^{3} \mathrm{H}\right]$-thymidine, and then cells will be harvested onto glass fiber filters. The incorporated radioactivity was counted using a Beta scintillation counter (MicroBeta Trilux, PerkinElmer Life Sciences). Cells treated without any stimuli were used as negative control. The immunosuppressive activity of each compound was expressed as the concentration of compound that inhibited ConA induced T cell proliferation or LPS-induced $\mathrm{B}$ cell proliferation to $50 \%\left(\mathrm{IC}_{50}\right)$ of the control value. Both the cytotoxicity and proliferation assessment repeated twice. Cyclosporin A (CsA) an immunosuppressive agent, was used as a positive control (Table 2; Additional file 1: Figs. S1-S24).

\section{Supplementary Information}

The online version contains supplementary material available at https://doi. org/10.1007/s13659-022-00327-2.

\section{Additional file 1: Figure S1. ${ }^{1} \mathrm{H}$ NMR $(600 \mathrm{MHz}, \mathrm{CD} 3 \mathrm{OD})$ spectrum of compound 1. Figure S2. ${ }^{13} \mathrm{C}$ NMR (150 MHz, CD3OD) spectrum of com- pound 1. Figure S3. HSQC spectrum of compound 1. Figure S4. COSY spectrum of compound 1. Figure S5. HMBC spectrum of compound 1. Figure S6. HRESIMS of compound 1. Figure S7. UV spectrum of com- pound 1. Figure S8. IR spectrum of compound 1. Figure S9. ${ }^{1} \mathrm{H}$ NMR (600 $\mathrm{MHz}, \mathrm{CD} 3 \mathrm{OD})$ spectrum of compound 2. Figure $\mathbf{S 1 0} .{ }^{13} \mathrm{C} \mathrm{NMR}(150 \mathrm{MHz}$, CD3OD) spectrum of compound 2. Figure S11. HSQC spectrum of com- pound 2. Figure S12. COSY spectrum of compound 2. Figure S13. HMBC spectrum of compound 2. Figure S14. HRESIMS of compound 2. Figure S15. UV spectrum of compound 2. Figure S16. IR spectrum of compound 2. Figure S17. ${ }^{1} \mathrm{H}$ NMR ( $\left.500 \mathrm{MHz}, \mathrm{CD} 3 \mathrm{OD}\right)$ spectrum of compound 3. Figure S18. ${ }^{13} \mathrm{C}$ NMR (126 MHz, CD3OD) spectrum of compound 3. Figure S19. HSQC spectrum of compound 3. Figure S20. COSY spectrum of compound 3. Figure S21. HMBC spectrum of compound 3. Figure S22. HRESIMS of compound 3. Figure S23. UV spectrum of compound 3. Figure S24. IR spectrum of compound 3.}

\section{Acknowledgements}

This work was supported by National Natural Science Foundation of China (grant No. 31870513, 32000011). We thank the Analytical \& Measuring Center, School of Pharmaceutical Sciences, SCUN for their help with NMR measurements. 


\section{Authors' contributions}

All authors read and approved the final manuscript.

\section{Funding}

National Natural Science Foundation of China (31870513), Zheng-Hui Li, National Aerospace Science Foundation of China (32000011), Hong-Lian Ai.

\section{Declarations}

\section{Competing interests}

The authors declare no conflict of interest.

Received: 4 September 2021 Accepted: 8 November 2021

Published online: 24 February 2022

\section{References}

1. Chen HP, Zhao ZZ, Cheng GG, Zhao K, Han KY, Zhou L, Feng T, Li ZH, Liu JK. Immunosuppressive nor-isopimarane diterpenes from cultures of the fungicolous fungus Xylaria longipes HFG1018. J Nat Prod. 2020;83:401-12.

2. Lleo A, Invernizzi P, Gao B, Podda M, Gershwin ME. Definition of human autoimmunity-autoantibodies versus autoimmune disease. Autoimmun Rev. 2010;9:A259-66.

3. Gao Y, Duan FF, Liu L, Peng XG, Meng XG, Ruan HL. Hypothemycin-type resorcylic acid lactones with immunosuppressive activities from a Podospora sp. J Nat Prod. 2021;84:483-94.

4. Feng T, Duan KT, He SJ, Wu B, Zheng YS, Ai HL, Li ZH, He J, Zuo JP, Liu JK. Ophiorrhines A and B, two immunosuppressive monoterpenoid indole alkaloids from Ophiorrhiza japonica. Org Lett. 2018;20:7926-8.

5. Shou QY, Fu RZ, Tan Q, Shen ZW. Geranylated flavonoids from the roots of Campylotropis hirtella and their immunosuppressive activities. J Agric Food Chem. 2009;57:6712-9.

6. Kiuchi M, Adachi K, Kohara T, Minoguchi M, Hanano T, Aoki Y, Mishina T, Arita M, Nakao N, Ohtsuki M, Hoshino Y, Teshima K, Chiba K, Sasaki S, Fujita T. Synthesis and immunosuppressive activity of 2-substituted 2-aminopropane-1,3-diols and 2-aminoethanols. J Med Chem. 2000:43:2946-61.

7. Ujam NT, Ajaghaku DL, Okoye FBC, Esimone CO. Antioxidant and immunosuppressive activities of extracts of endophytic fungi isolated from Psidium guajava and Newbouldia laevis. Phytomedicine Plus. 2021;1: 100028

8. D'Alessio R, Bargiotti A, Carlini O, Colotta F, Ferrari M, Gnocchi P, Isetta A, Mongelli N, Motta P, Rossi A, Rossi M, Tibolla M, Vanotti E. Synthesis and immunosuppressive activity of novel prodigiosin derivatives. J Med Chem. 2000:43:2557-65

9. Liu J, Li H, Chen KX, Zuo JP, Guo YW, Tang W, Li XW. Design and synthesis of marine phidianidine derivatives as potential immunosuppressive agents. J Med Chem. 2018;61:11298-308.

10. Johnston A. Equivalence and interchangeability of narrow therapeutic index drugs in organ transplantation. Eur J Hosp Pharm. 2013;20:302-7.

11. Smith JM, Nemeth TL, McDonald RA. Current immunosuppressive agents: efficacy, side effects, and utilization. Pediatr Clin N Am. 2003;50:1283-300.

12. Gordaliza M, Faircloth GT, Castro MA, Miguel del Corral JM, LópezVázquez ML, San FA. Immunosuppressive cyclolignans. J Med Chem. 1996;39:2865-8

13. Li G, Kusari S, Lamshoft M, Schuffler A, Laatsch H, Spiteller M. Antibacterial secondary metabolites from an endophytic fungus, Eupenicillium sp. LG41. J Nat Prod. 2014;77:2335-41.

14. Lin X, Lu C, Huang Y, Zheng Z, Su W, Shen Y. Endophytic fungi from a pharmaceutical plant, Camptotheca acuminata: isolation, identification and bioactivity. World J Microbiol Biotechnol. 2007;23:1037-40.

15. Chen HJ, Awakawa T, Sun JY, Wakimoto T, Abe I. Epigenetic modifierinduced biosynthesis of novel fusaric acid derivatives in endophytic fungi from Datura stramonium L. Nat Prod Bioprospect. 2013;3:20-3.

16. Feng L, Wang J, Liu S, Zhang XJ, Bi QR, Hu YY, Wang Z, Tan NH. Colletopeptides A-D, anti-inflammatory cyclic tridepsipeptides from the plant endophytic fungus Colletotrichum sp. S8. J Nat Prod. 2019:82:1434-41.
17. Kuang C, Jing SX, Liu Y, Luo SH, Li SH. Drimane sesquiterpenoids and Isochromone derivative from the endophytic fungus Pestalotiopsis sp. M-23. Nat Prod Bioprospect. 2016:6:155-60.

18. Kim D, Simborio HL, Reyes AW, Min W, Lee HJ, Lee J, Chang H, Kim D. Antibacterial effects of Coptis chinensis Franch against Brucella abortus. J Agric Life Sci. 2014;48:107-14.

19. Fan $\mathrm{DL}$, Xiao XH, Ma XJ. Calorimetric study of the effect of protoberberine alkaloids in Coptis chinensis Franch on Staphylococcus aureus growth. Thermochim Acta. 2008:480:49-52.

20. Zhang XH, Zhang DJ, Liu JL, Pan HY, Qin JC, Zhang YH. Antifungal effects of volatile organic compounds from the endophytic fungus Cryptosporiopsis ericae Cc-HG-7 isolated from Coptis chinensis Franch. Biocontrol Sci Technol. 2018;28:496-508.

\section{Publisher's Note}

Springer Nature remains neutral with regard to jurisdictional claims in published maps and institutional affiliations.

\section{Submit your manuscript to a SpringerOpen ${ }^{\circ}$ journal and benefit from:}

- Convenient online submission

- Rigorous peer review

- Open access: articles freely available online

- High visibility within the field

- Retaining the copyright to your article

Submit your next manuscript at $\boldsymbol{\nabla}$ springeropen.com 